\title{
A Regional Analysis of Credit Needs and the Unmet Demand for Microfinance
}

\author{
A. S. De Alwis
}

\begin{abstract}
This paper compares and contrasts borrowing patterns of households at the bottom of the pyramid with those of the non-poor in the seven provinces, Western, Central, Southern, North Western, North Central, Uva, and Sabaragamuwa in order to determine the features required to be incorporated in microfinance products to make them low-end market friendly. The information reveals that regional disparity is much greater than income wise disparity in borrowing patterns pointing to the fact that there is no strong case for designing specific loan products for the poor. Overall however, as expected, the poor had lesser access to institutional credit and expended proportionately more of their borrowing for consumption and other non-productive purposes than the non-poor. However, financial inclusion among the poor was found to be much greater in this country when compared to other countries in the region. Despite high financial inclusion among the poor, both the poor and the non-poor tend to borrow from the informal sector as well, particularly from friends and relatives. The poor in the Southern Province had greater dependence on informal sector credit despite the high financial inclusion reported from that province. Figures on financial inclusion indicate that the number of households still to be reached by poverty alleviation microfinance programmes in these seven provinces was below 300,000. Resource requirement for initial loans to be provided to these persons in order to enroll them in a poverty alleviation microfinance programme was estimated to be less than Rs. 6 billion.
\end{abstract}




\section{A Regional Analysis of Credit Needs and the Unmet Demand for Microfinance}

\section{Introduction}

The poor require financial services particularly savings services and credit as much as do the rich, or even more. Among financial services, savings services are considered to be the most important for the poor because their incomes are often irregular and seasonal and they do not have access to risk management instruments like insurance. Accordingly, the poor need savings for consumption smoothing (i.e., to meet consumption needs during the period they do not earn income) and for working capital (e.g. meeting cultivation costs in the case of cultivators). Further, savings are needed to meet unanticipated expenditure arising out of emergencies and man-made/natural disasters, to which the poor are more vulnerable and for which they do not usually have insurance cover. Other reasons for which they require savings include life cycle events such as births, deaths and marriages, education and health expenditure, exploiting of investment opportunities when they arise, business activities, purchase of productive assets and construction and improvements of houses. The poor require to borrow for the same purposes for which they require to save. Access to credit enables the poor to engage in income generating activities and to manage the growth and diversification of these activities.

Formal financial institutions often do not meet the financial service needs of the poor. Institutions such as banks which are driven by the profit motive are often reluctant to provide savings services to the poor because maintaining a large number of very small accounts is more costly than maintaining a few large accounts. Imposition of minimum deposit requirements for the opening and maintaining of bank deposits and placing restrictions on the frequency of fund withdrawal are some of the means by which the poor are excluded from banking services. Further, the required formalities for opening bank accounts, such as completion of numerous forms, providing documents of identity etc. sometimes tend to intimidate the poor, particularly if they are not well educated. As a result, the poor are often forced to use alternative methods of saving such as accumulating excess funds at home and/or saving in kind (e.g.: accumulating gold, livestock and consumer durables). They also tend to use "informal' savings arrangements such as rotating savings and credit associations (ROSCAs), mutual aid societies etc., to save. Yet these forms of saving suffer from many disadvantages. For example, the poor will find it difficult to resist spending money saved at home, while investment in kind cannot be liquidated easily to meet contingency requirements. Similarly, funds in ROSCAs are also difficult to access in times of need.

Financial institutions are also in general reluctant to lend to the poor because they lack assets that could be used as collateral, which makes them high risk customers. 
Further, the poor tend to borrow in small amounts and often live in inaccessible regions. A higher level of interaction is also required with poor borrowers to ensure loan recovery. All these factors make the provision of loans to the poor more expensive to banks. Further, when borrowing for income generating activities, the poor are unable to provide acceptable business plans. Risks of lending to poor agricultural communities are further enhanced by the high covariance of rural incomes, which would result in heavy defaults in the event of crop failure or adverse climatic conditions for cultivation. The poor, on their part, are also reluctant to approach formal financial institutions both because they lack acceptable collateral and because the procedure involved in dealing with formal financial institutions is costly, time consuming and complex, particularly if the credit seeker is ill educated. As a result, even at present, the credit needs of the poor, particularly in developing countries are being largely met by informal arrangements and a notable proportion of the poor remain unbanked. Due to the limited flow of funds from the formal financial sector to the poor, informal money lenders continue to have a thriving business when meeting the credit needs of the poor. Loans provided by money lenders generally involve high interest rates and servicing these loans results in the poor sinking further into poverty. It is now increasingly accepted that lack of access to financial services lies at the root of persistent poverty and inequality problems in most developing societies.

Various schemes have been in operation the world over, even prior to the 1970s, for delivery of credit to the poor. However, the perception four decades or more ago was that lending to the poor was not commercially viable and should therefore be undertaken by the government and/or "not for profit" NGOs. Early schemes for providing credit to the poor were accordingly often government directed and due to flaws in their design and political influence $e t c$., often unsuccessful. As such programmes often suffered from significant loan default rates, they were generally not sustainable and were of limited outreach.

In the mid 1970s the perception with regard to the bankability of the poor underwent a revolutionary transformation when noble laureate Professor Mohamud Yunus exploded the myth that the poor do not repay loans. The Nobel Prize for peace was awarded to Prof. Yunus recently in recognition of the role poverty alleviation plays in sustaining stability and peace in society. During the last 2-4 decades, financial services provided for the poor which came to be known collectively as "Microfinance Services" have developed rapidly due to commercialisation. Microfinance has now been accepted as a new development paradigm for alleviation of poverty through the social and economic empowerment of the poor.

\section{What is Microfinance?}

The definition of Microfinance has undergone substantial transformation over the years. In the early years, Microfinance was considered to merely be a credit methodology that 
employed effective collateral substitutes to deliver and recover short term working capital loans to micro entrepreneurs or potential micro entrepreneurs. However, at present, the definition has been broadened to include an array of financial services provided to low income households including savings, insurance and money transfer. Even now, official definitions vary and even in countries like India, where the micro finance sector is relatively prominent, there is no single uniformly accepted definition of Microfinance. In Sri Lanka's proposed Microfinance Act, the definition for Microfinance is as follows:

"Micro finance business means acceptance of deposits or receiving and/or obtaining external funds and providing financial accommodation in any form and other financial services, mainly to low income persons and to small and micro enterprises (external funds" referred to here means grants, donations, borrowings, security deposits and any other sources of funds that may be specified by the (Monetary) Board from time to time)."

The Asian Development Bank defines Microfinance more simply as the provision of a broad range of financial services such as deposits, loans, payment services, money transfers and insurance to poor and low-income households and their micro enterprises.

Sometimes Microfinance is defined even more broadly, to cover activities related to skill upgrading and entrepreneurial development of the poor, that are aimed at lifting them out of poverty.

Use of both the terms "poor" and "low-income" households above is significant as it implies that Microfinance is not a service to be exclusively limited only to those in poverty (i.e., those below a country's official poverty line), although it has been recognized globally as an effective poverty alleviation tool. Low income households just above the poverty line (the near poor) also are a vulnerable group liable to experience transitory poverty from time to time owing to shocks such as natural and man-made disasters etc. Even if this was not so, the enterprises operated by the near poor are usually micro enterprises, which employ persons poorer than themselves. Therefore, it is argued that by the ripple affect of microfinance, it is possible to reach out to the ultra poor who do not have the capacity or inclination to become entrepreneurs in their own right by providing support to micro enterprises belonging to the near poor in which the ultra poor are employed. Further, by having as clients those that are "less poor" Microfinance Institutions (MFIs) would become more sustainable than would be the case if they limited their activities to serving only the ultra poor and the cost of finance to the ultra poor would also be thereby reduced.

The first part of this study will analyse borrowing patterns of low income households on a regional basis in order to identify specifically the credit needs of the poor and to 
obtain insights on features that could be incorporated into microfinance products in different regions in Sri Lanka to make them low-end market friendly. All households in a province below the poverty line and 5 per cent of households just above the poverty line are considered to be households in need of microfinance services, for the purpose of this study. Using a terminology that has gained currency recently, these households would be henceforth referred to as those at the Bottom of the Economic Pyramid (BOP households), while all other households are to be classified as non-poor (NP). The estimates of unbanked BOP households on a provincial basis undertaken in the second part of the study would give an indication of the potential available for expanding micro finance services regionally, and would therefore be useful in identifying the geographical areas which should be given priority when pursuing the goal of financial inclusion of the poor. This figure would in fact represent an aspect of the unmet demand for microfinance. An estimate is also made of the initial resources required to enroll the unbanked BOP households in poverty alleviation microfinance schemes. The estimates made in this part of the study would be useful not only to policy makers but also for financial institutions, NGOs and other agencies involved in microfinance delivery.

Borrowing patterns of BOP and non-poor households are analysed in this paper on a provincial basis using data from the Consumer Finance and Socio Economic Survey (CFSES) of the Central Bank 2003/04. The present unmet demand for microfinance, that is the number of households in the BOP category which are unbanked, is also estimated using CFSES data for 1996/97 and 2003/2004 and future projections are made under two broad assumptions.

The CFSES 2003/2004 collected details of loans taken by households in the 6 month period immediately prior to the date of enumeration of the household as well as all loans taken outside this reference period, in respect of which payment of interest and principle was undertaken during the reference period. Information on the source of borrowing, purpose of borrowing, interest rate under which credit was obtained and security provided for such credit are available by household income decile. However, the CFSES did not collect information on the ownership of bank accounts by households, but collected data on credits and debits to bank accounts (inclusive of crediting of interest) during the reference period of 6 months. Due to these limitations in the data, a household was considered to have access to formal financial institutions if it:

(a) had undertaken any transactions relating to its financial assets such as crediting and/or debiting bank accounts within the 6 month period prior to the date of enumeration, or

(b) had interest credited to it from a financial institution during the same period, or 
(c) had obtained a loan from a financial institution or made capital/interest payments on a loan obtained earlier from a financial institution during the same period.

All other households were defined to be those without access to formal financial services.

\section{Limitations of Data}

Estimates of the unmet demand for micro finance are subject to limitations owing to the assumptions mentioned earlier on the basis of which financially excluded households were identified. Financial assets, for the purpose of this survey, were defined to be savings accounts (in banks), term deposits (in banks and finance companies), government securities and private sector investments. Households not having access to banks are unlikely to invest in government securities or own shares, debentures etc. Therefore, it is quite safe to assume that all households undertaking transactions relating to assets have access to formal financial institutions. Accordingly, it is highly unlikely that the number of unbanked households would be under-estimated by employing this assumption. However, there is a likelihood of under estimation of financial inclusion when using this methodology. In this paper the undermentioned categories of households which ideally should be counted as financially included would be deemed to be financially excluded.

(a) Households holding current accounts only which have not undertaken any loan transactions (obtaining of a loan, payment of capital or interest) during the reference period of 6 months prior to date of enumerations.

(b) Households without fixed/savings account which have loans taken earlier in respect of which no payment has been made during the reference period.

(c) Households which have access to formal financial institutions but choose not to use them including those who had dealt with financial institutions in the past but no longer do so (These households are described as the self-excluded in the literature).

It is therefore clear that there is some underestimation of financial inclusion with households in the category (a) - (c) being deemed to be financially excluded whereas they are in fact financially included. The situation described in (a) would be more frequent among the non-poor than the poor, and therefore the unbanked poor will not be greatly over estimated even if households in category (a) are considered to be financially excluded. The situation described in (b) would arise if the loanee household was enjoying a grace period in respect of loan repayment during the reference period or was defaulting on loan repayment. The situation described in (c) would mostly arise in instances where financial access is 
partial; with the financial products offered being either not useful or difficult to access due to obstacles being placed on access. Households belonging to category (c) therefore often lack full access to finance and no significant bias is created in the analysis by considering them to be without access to financial institutions. In fact, as it is difficult to estimate the number of households self-excluded, it is the usual the practice of researchers to use the utilization of financial services as a proxy for access to finance.

The foregoing makes it clear that the figures derived here should be considered to represent upper bounds for unmet demand for microfinance.

Borrowing patterns of BOP households are determined using information on borrowing of households by income deciles. As this information is only available by income decile, it was necessary to use linear interpolation methods to make estimates relating to BOP and non-poor households which would therefore be only approximations. However, this level of accuracy is sufficient to reveal broad trends. Another shortcoming of the analysis is that information is not available for the Northern and Eastern Provinces for which poverty lines are not available. The analysis is therefore limited to 7 provinces.

\section{BOP Households}

In Sri Lanka, there is wide variation in the level of poverty across the provinces as indicated in Chart 1 and Table 1, [which give the poverty headcount, the estimated

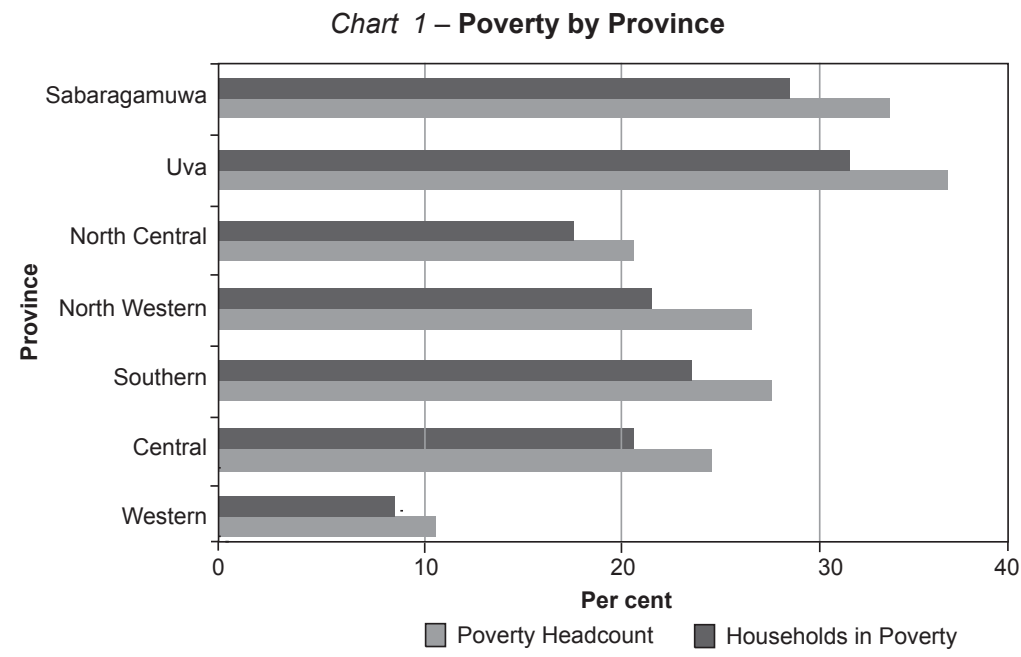

Source : Department of Census and Statistics Household Income and Expenditure Survey 2002 
proportion of households in poverty and the poverty density (number of poor per square kilo meter) by province]. These statistics were based on the percentage of households in poverty as estimated by the Department of Census and Statistics in its Household Income and Expenditure Survey (HIES) 2002. Although more recent poverty statistics are available, HIES 2002 data is used owing to the fact that it was the closest year to the CFSES 2003/04. The table also gives the proportion of BOP households in each province estimated as explained earlier.

Table 1 - Provincial Poverty and BOP Households

\begin{tabular}{|l|c|c|c|c|}
\hline \multicolumn{1}{|c|}{ Province } & $\begin{array}{c}\text { Poverty } \\
\text { Headcount }\end{array}$ & $\begin{array}{c}\text { Percentage of Households } \\
\text { in Poverty }\end{array}$ & $\begin{array}{c}\text { BOP } \\
\text { Households }\end{array}$ & $\begin{array}{c}\text { Poverty } \\
\text { Density }\end{array}$ \\
\hline Western & 11 & 9 & 14 & 166 \\
Central & 25 & 21 & 26 & 110 \\
Southern & 28 & 24 & 29 & 120 \\
NWP & 27 & 22. & 27 & 61 \\
NCP & 21 & 18. & 23 & 31 \\
Uva & 37 & 32 & 37 & 53 \\
Sabaragamuwa & 34 & 29 & 34 & 125 \\
\hline
\end{tabular}

Source : Department of Census and Statistics HIES 2002

The data in Table 1 indicates that of the seven provinces considered, poverty in terms of headcount and proportion of households in poverty was greatest in the Uva Province and least in the Western Province. However, statistics of poverty density reveal a completely different story with the highest figure being recorded in the Western province at 166 poor persons per square $\mathrm{km}$ while the lowest figure was recorded in the NCP. Tables 2-5 below give the borrowing patterns of BOP and non-poor households.

\section{Purpose of Borrowing-BOP and Non-Poor Households}

Table 2 gives a comparison of the distribution of the number of loans by purpose for BOP and non-poor households on a regional basis, while Chart 2 gives the distribution of the number of loans for productive purposes, housing and other purposes by province. The distribution of the value of loan by major purposes and sources for BOP and non-poor households is given in Table 3. 
Table 2 - Distribution of Number of Loans by Purpose of Borrowing BOP and Non-Poor households

\begin{tabular}{|c|c|c|c|c|c|c|c|c|c|c|c|c|c|c|}
\hline & \multicolumn{2}{|c|}{ Western } & \multicolumn{2}{|c|}{ Central } & \multicolumn{2}{|c|}{ Southern } & \multicolumn{2}{|c|}{ NWP } & \multicolumn{2}{|c|}{ NCP } & \multicolumn{2}{|c|}{ Uva } & \multicolumn{2}{|c|}{ Sabaragamuwa } \\
\hline & BOP & NP & BOP & $\mathrm{NP}$ & BOP & $\mathrm{NP}$ & BOP & $\mathrm{NP}$ & BOP & $\mathrm{NP}$ & BOP & NP & BOP & $\mathrm{NP}$ \\
\hline Paddy Cultivation & 1.5 & 0.5 & 2.9 & 1.4 & 5.2 & 3.5 & 3.2 & 6.1 & 27.3 & 22.9 & 6.6 & 3.2 & 1.4 & 2.0 \\
\hline Other Crops & 1.5 & 0.3 & 12.1 & 10.9 & 5.9 & 2.5 & 5.0 & 2.0 & 9.8 & 8.9 & 13.7 & 13.9 & 7.8 & 3.0 \\
\hline Livestock & 0 & 0.5 & 1.4 & 0.4 & 0 & 0.7 & 1.0 & 2.4 & 0.8 & 0.7 & 0.8 & 0.2 & 0.9 & 0.0 \\
\hline Industry & 5.9 & 1.1 & 0.5 & 0.6 & 1.3 & 1.3 & 1.8 & 1.7 & 0 & 0.7 & 0 & 0 & 0 & 2.0 \\
\hline Business / Trade & 1.5 & 9.5 & 2.2 & 7.5 & 3.4 & 8.9 & 6.4 & 10.7 & 3.3 & 8.5 & 5.1 & 14.3 & 3.2 & 10.1 \\
\hline Housing & 5.9 & 13.4 & 9.5 & 10.8 & 11.9 & 14.1 & 11.8 & 13.8 & 4.7 & 6.5 & 8.8 & 12.4 & 13.5 & 17.3 \\
\hline Consumption & 63.2 & 41.9 & 44.8 & 24.5 & 49.1 & 32.3 & 41.9 & 25.4 & 31.8 & 19.4 & 42.5 & 26.6 & 43.1 & 23.3 \\
\hline Ceremonial / Ritual & 1.5 & 12 & 16.6 & 27.5 & 7.7 & 16.9 & 3.8 & 8.6 & 6.9 & 9.4 & 9.6 & 15.5 & 14.9 & 19.7 \\
\hline Settlement of Dues & 7.4 & 8.4 & 4.8 & 5.5 & 5.2 & 6.4 & 12.8 & 11.6 & 6 & 9.1 & 3.9 & 3.5 & 5.3 & 9.5 \\
\hline Consumer Durables & 0 & 5.2 & 0.3 & 4.1 & 3.1 & 4.7 & 2.1 & 8.4 & 2.2 & 5.8 & 2.6 & 3.3 & 2.1 & 6.6 \\
\hline Other & 11.8 & 7.2 & 5 & 6.5 & 7.2 & 8.8 & 10.2 & 9.4 & 7.2 & 8.2 & 6.5 & 7.3 & 8.9 & 5.6 \\
\hline Not Specified & 0 & 0 & 0 & 0 & 0 & 0 & 0 & 0 & 0 & 0 & 0 & 0 & 0 & 0.0 \\
\hline Total & 100.0 & 100.0 & 100.0 & 100.0 & 100.0 & 100.0 & 100.0 & 100.0 & 100.0 & 100.0 & 100.0 & 100.0 & 100.0 & 100.0 \\
\hline Productive Purposes & 10.3 & 11.9 & 19.1 & 20.9 & 15.9 & 16.9 & 17.4 & 22.9 & 41.3 & 41.7 & 26.2 & 31.4 & 13.4 & 17.0 \\
\hline Housing & 5.9 & 13.4 & 9.5 & 10.8 & 11.9 & 14.1 & 11.8 & 13.8 & 4.7 & 6.5 & 8.8 & 12.4 & 13.5 & 17.3 \\
\hline Other Purposes & 83.8 & 74.6 & 71.5 & 68.3 & 72.2 & 69.0 & 70.8 & 63.4 & 54.1 & 51.8 & 65.1 & 56.2 & 73.2 & 64.8 \\
\hline Total & 100.0 & 100.0 & 100.0 & 100.0 & 100.0 & 100.0 & 100.0 & 100.0 & 100.0 & 100.0 & 100.0 & 100.0 & 100.0 & 100.0 \\
\hline
\end{tabular}

The table above indicates that in terms of numbers, loans taken for consumption and other less productive purposes substantially exceeds loans taken for productive purposes in all provinces. In terms of value also this situation prevails in all provinces, (other than in the case of the non-poor in the Western Province), although the disparity is comparatively less, as loans taken for productive purposes are generally of greater value than those taken for other purposes such as consumption (see Table 3). In terms of numbers, loans taken for productive purposes was greater for the "non-poor" category of households than for BOP households in all provinces, although in the NCP, income wise disparity was insignificant. Meanwhile, table 3 indicates that in value terms, loans devoted for productive purposes by the non-poor category exceeds the corresponding proportion for the BOP category in all provinces except in the Southern Province and NCP. In fact, in the NCP, where both in terms of numbers and values, loans for productive purposes were relatively high, the value of loans devoted for productive purposes by BOP households significantly exceeded the corresponding figure for the non-poor category. 


\section{Chart 2- Distribution of Loans by Purposes}

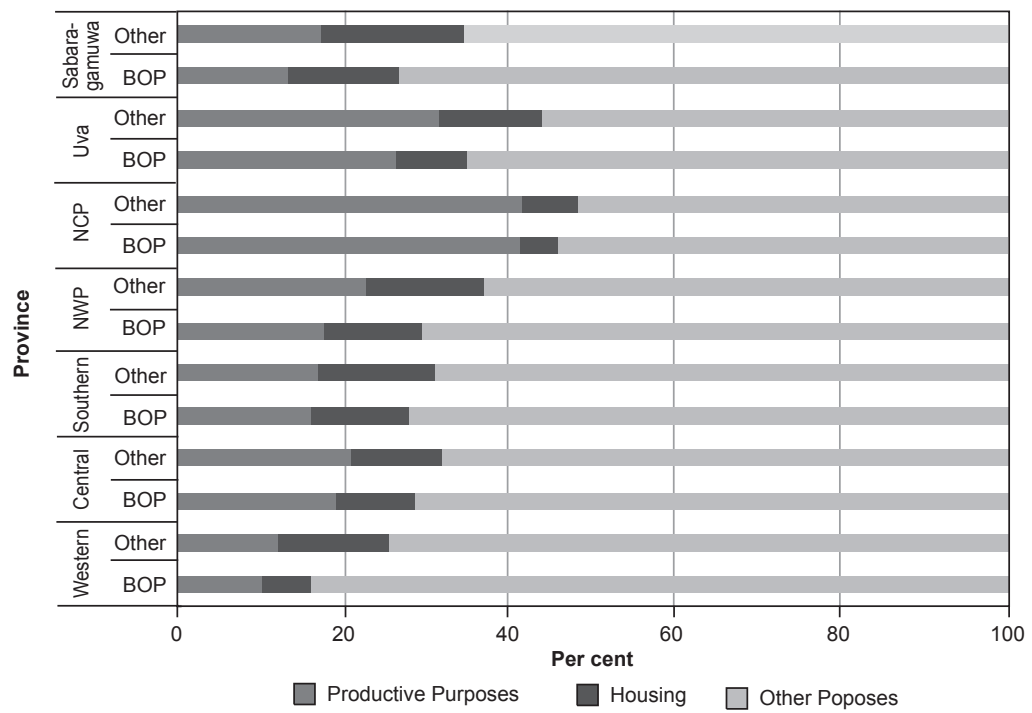

Source : Central Bank of Sri Lanka, Consumer Finance and Socio Economic Survey (CFSES) 2003/04

There is a significant province wise disparity and in fact such disparity is much more evident than poor - non-poor disparity in borrowing patterns within a province. In terms of numbers, the share of loans taken for productive purposes is significantly higher among households in the NCP when compares with other provinces. As much as 41.3 per cent of the number loans of BOP households and 41.7 per cent of the number loans of the non-poor category in the NCP were for productive purposes. It was observed above that in value terms, the proportion of loans devoted to productive purposes by BOP households in fact exceeded that of the non-poor group in the NCP. When the detailed breakdown of the number of loans is considered, it is clear that the bulk of these loans pertain to those obtained for agricultural activities. In fact, the proportion of loans obtained for paddy cultivation by the BOP households in the NCP exceeds marginally that of the non-poor category of households. It will be seen later, that the bulk of these loans have been obtained from institutional sources. These statistics reflect the level of success achieved by schemes such as the New Comprehensive Rural Credit Scheme (NCRCS) and schemes operated by the National Development Trust Fund in reaching poorest groups in the NCP. In these schemes, proportionately more credit is provided to the NCP when compared to other provinces. It is also observed that next to the Western Province, poverty levels were least in the NCP which suggests that these targeted loan schemes may have helped to contain rural poverty to a certain extent in the province. Ranking next to the NCP in the proportion of loans taken for 
productive activities was the Uva Province. However, in this case, a larger number of loans has been taken for cultivation of crops other than paddy which could be expected given that cultivation of crops such as vegetables and potatoes is undertaken on a significant scale in the Province. Loans given for livestock was generally low (below 2 per cent of the total number of loans) in all provinces as were loans given for industries. Proportion of total loans obtained for trade and business was significantly higher for the non-poor category when compared with the BOP category in all provinces; the relevant proportion varying between 7.5 per cent in the Central Province and 14.3 per cent in the Uva province for the non-poor category and between 1.5 per cent in the Western province and 6.4 per cent in the NWP, for the BOP category.

The proportion of loans taken for housing purposes was greater for the non-poor category when compared to the BOP households. In all provinces other than the Western Province, the proportion of the value of loans devoted to housing by the non-poor category also exceeded the relevant proportion for the BOP households as could be expected given that the non-poor would aspire for better housing facilities. The figures for the Western Province for the distribution of the value of loans for housing seems to be an outlier, which was probably caused by just a few large housing loans taken by BOP households. Interestingly, the highest proportion of loans for housing was reported in the Sabaragamuwa Province; this share being 13.5 per cent among the BOP households and 17.3 per cent among the non-poor group. In terms of value of loans, the proportion devoted to housing by the non-poor in the Sabaragamuwa province exceeded the corresponding proportion for BOP households by a wide margin indicating, that good quality housing is a priority for the non-poor in that province.

Meanwhile, among BOP households in the Western Province, the total value of loans devoted to productive purposes was significantly low at 6.7 per cent reflecting partly the occupation mix in this most urbanized of provinces. Loans for productive purposes are taken mainly by the self employed and employer categories, and the relatively lower proportion of households in the Western Province in this category is probably reflected in the low share of the value of loans devoted to productive purposes.

As observed earlier, in terms of numbers, consumption activities accounted for a much higher proportion of loans among BOP households when compared with the non-poor category. This reflects the fact that the poor frequently have to borrow to meet their day to day basic needs including food fuel and clothing whereas the more affluent are generally able to meet such needs out of their incomes, and only resort to borrowing for consumption purposes under special circumstances. In terms of number of loans, the highest borrowing for consumption was recorded in the Western Province where 63.2 per cent of loans taken by BOP households and 41.9 per cent of loans taken by the non-poor category were for 
consumption expenditure. Comparison of Table 2 and 3 indicates that such loans are of lesser value than those for productive activities. Loans for ceremonials and rituals, which include life cycle events, was significantly lower among BOP households when compared to the non-poor category in all provinces. There was considerable province-wise variation in this share, with the highest proportion of loans for both groups being registered in the Central Province where 16.6 per cent of loans of the BOP category and 27.5 per cent of loans of the non-poor category were for ceremonials and rituals. These borrowing patterns probably reflect regional variations in social obligations and traditions. The comparatively low proportion of loans taken for ceremonials and rituals by BOP households in the Western Province probably reflects the fact that urbanization has eroded traditions to some extent and as a result, the poor in the Western Province choose to dispense with such ceremonies and rituals, due to financial constraints. Loans for settlement of debt also displayed substantial regional diversity with the highest figures for both the BOP households (12.8 per cent) and non-poor category (11.6 per cent) being registered in the NWP.

The above analysis confirms the pressing need for the poor to borrow in small amounts for their basic consumption requirements. Having to service a heavy debt burden on account of basic consumption requirements is likely to discourage them from borrowing further to establish income generating activities, impairing their ability to move out of poverty.

Table 3 - Distribution of the Value of Loans by Major Purposes and Sources

\begin{tabular}{|c|c|c|c|c|c|c|c|c|c|c|c|c|c|c|}
\hline & \multicolumn{2}{|c|}{ Western } & \multicolumn{2}{|c|}{ Central } & \multicolumn{2}{|c|}{ Southern } & \multicolumn{2}{|c|}{$\mathrm{NCP}$} & \multicolumn{2}{|c|}{ NWP } & \multicolumn{2}{|c|}{ Uva } & \multicolumn{2}{|c|}{ Sabaragamuwa } \\
\hline & BOP & NP & BOP & NP & BOP & NP & BOP & NP & BOP & NP & BOP & NP & BOP & NP \\
\hline \multicolumn{15}{|l|}{ Purpose } \\
\hline Productive & 6.7 & 42.4 & 30.9 & 33.6 & 18.3 & 12.6 & 37.1 & 32.7 & 15.1 & 24.6 & 32.4 & 36.8 & 21.3 & 24.0 \\
\hline Housing & 62.3 & 22.5 & 19.6 & 28.0 & 16.1 & 27.1 & 4.2 & 12.8 & 23.8 & 27.0 & 21.9 & 26.9 & 27.0 & 32.7 \\
\hline Other & 31.0 & 35.1 & 49.4 & 38.4 & 65.6 & 60.2 & 58.7 & 54.5 & 61.1 & 48.5 & 45.7 & 36.2 & 51.7 & 43.3 \\
\hline Total & 100.0 & 100.0 & 100.0 & 100.0 & 100.0 & 100.0 & 100.0 & 100.0 & 100.0 & 100.0 & 100.0 & 100.0 & 100.0 & 100.0 \\
\hline \multicolumn{15}{|l|}{ Source } \\
\hline Formal / Semi-formal & 75.6 & 59.2 & 71.6 & 79.1 & 47.6 & 73.2 & 53.9 & 83.9 & 65.1 & 68.8 & 68.6 & 80.3 & 55.0 & 82.2 \\
\hline Informal & 24.4 & 40.8 & 28.4 & 20.9 & 52.4 & 26.8 & 46.1 & 16.1 & 34.9 & 31.2 & 31.4 & 19.7 & 45.0 & 17.8 \\
\hline Total & 100.0 & 100.0 & 100.0 & 100.0 & 100.0 & 100.0 & 100.0 & 100.0 & 100.0 & 100.0 & 100.0 & 100.0 & 100.0 & 100.0 \\
\hline
\end{tabular}


Table 4-Comparison of the Distribution of Loans by Source-BOP and Non-Poor Households

\begin{tabular}{|c|c|c|c|c|c|c|c|c|c|c|c|c|c|c|}
\hline \multirow{2}{*}{ Source } & \multicolumn{2}{|c|}{ Western } & \multicolumn{2}{|c|}{ Central } & \multicolumn{2}{|c|}{ Southern } & \multicolumn{2}{|c|}{ NWP } & \multicolumn{2}{|c|}{$\mathrm{NCP}$} & \multicolumn{2}{|c|}{ Uva } & \multicolumn{2}{|c|}{ Sabaragamuwa } \\
\hline & BOP & NP & BOP & NP & BOP & NP & BOP & NP & BOP & NP & BOP & NP & BOP & NP \\
\hline Commercial Banks & 24.7 & 29.2 & 29.0 & 32.5 & 13.2 & 17.5 & 25.7 & 22.8 & 38.8 & 40.0 & 27.3 & 38.3 & 17.0 & 22.3 \\
\hline Development Banks & 6.2 & 5.7 & 7.2 & 5.6 & 4.1 & 7.2 & 9.8 & 12.4 & 8.3 & 8.4 & 6.9 & 8.3 & 10.2 & 13.7 \\
\hline DFls & 0.0 & 0.9 & 0.0 & 1.7 & 0.7 & 3.6 & 0.8 & 1.7 & 0.8 & 0.6 & 1.0 & 1.5 & 1.0 & 3.1 \\
\hline Rural Banks / Co-operatives & 2.6 & 4.3 & 6.6 & 3.6 & 9.7 & 9.3 & 4.7 & 5.3 & 4.2 & 3.4 & 6.8 & 5.5 & 7.2 & 5.8 \\
\hline Samurdhi / Janashakthi Banks etc. & 3.4 & 1.5 & 6.3 & 4.2 & 7.3 & 3.1 & 5.6 & 3.4 & 5.5 & 4.5 & 8.0 & 1.3 & 7.3 & 3.8 \\
\hline Loan Boards / Thrift Societies & 2.1 & 1.4 & 0.9 & 0.8 & 3.4 & 4.5 & 2.1 & 3.8 & 3.5 & 5.5 & 4.7 & 3.2 & 0.7 & 2.2 \\
\hline Formal Sector Employers & 3.9 & 11.5 & 10.3 & 20.0 & 4.4 & 14.5 & 0.7 & 5.3 & 2.5 & 6.2 & 3.6 & 10.3 & 5.4 & 10.2 \\
\hline Finance / Leasing Companies & 4.1 & 3.0 & 0.0 & 0.6 & 0.0 & 0.3 & 0.5 & 1.2 & 0.0 & 1.2 & 0.3 & 0.2 & 1.4 & 2.8 \\
\hline NGOs & 0.0 & 0.4 & 1.7 & 1.4 & 0.0 & 1.1 & 2.8 & 0.6 & 2.9 & 2.6 & 1.4 & 1.0 & 0.5 & 1.2 \\
\hline Formal \& Semi-Formal Sources & 47.0 & 58.1 & 62.1 & 70.4 & 42.7 & 61.1 & 52.6 & 56.5 & 66.5 & 72.6 & 60.1 & 69.4 & 50.7 & 65.2 \\
\hline Money Lenders & 16.1 & 13.2 & 8.5 & 6.8 & 18.3 & 9.7 & 10.6 & 10.0 & 12.4 & 6.6 & 8.2 & 6.6 & 7.3 & 9.7 \\
\hline Friends and Relatives & 35.4 & 27.3 & 26.4 & 20.8 & 33.8 & 26.7 & 35.0 & 31.2 & 21.1 & 18.3 & 29.0 & 20.4 & 37.5 & 22.0 \\
\hline Other & 1.5 & 1.3 & 3.1 & 1.8 & 5.1 & 2.4 & 1.8 & 2.4 & 0.0 & 2.5 & 2.7 & 3.7 & 4.4 & 2.6 \\
\hline Not Specified & 0.0 & 0.0 & 0.0 & 0.0 & 0.0 & 0.0 & 0.0 & 0.0 & 0.0 & 0.0 & 0.0 & 0.0 & 0.0 & 0.4 \\
\hline Total & 100.0 & 100.0 & 100.0 & 100.0 & 100.0 & 100.0 & 100.0 & 100.0 & 100.0 & 100.0 & 100.0 & 100.0 & 100.0 & 100.0 \\
\hline
\end{tabular}

Source : Central Bank of Sri Lanka, CFSES 2003/04

Table 4 above gives the distribution of loans by source for BOP and non-poor households while Chart 3 gives the distribution of borrowing (in terms of the number of loans) of BOP households by selected major sources. As could be expected, the proportion of the total number of loans taken from formal and semiformal sectors was higher for the non-poor category when compared to BOP households in all provinces. When the distribution of the value of loans is considered, the disparity is even greater in provinces other than the Western Province. However, while formal and semi formal sources accounted for over 50 per cent of the number of loans taken by the non-poor category in all provinces, such sources also accounted for over 50 per cent of loans taken by BOP households in the Central, NWP, NCP, Uva and Sabaragamuwa Provinces as well, implying that even the poor have a fair exposure to formal sources of credit in these provinces. Share of loans obtained from formal sources by BOP households was least in the Southern Province (42.7 per cent) and greatest in the NCP (66.5 per cent). It is significant that in value terms loans from formal/semiformal sources accounted for over 50 per cent of loans in all provinces other than in the case of BOP category in the Southern Province, indicating that the Sri Lanka financial market has reached the stage of institutional predominance in credit. In the Southern Province however, 52.4 per cent of the value of loans of the BOP households was still supplied by informal sources. 


\section{Chart 3-Distribution of Loans by Selected Sources - BOP Households}

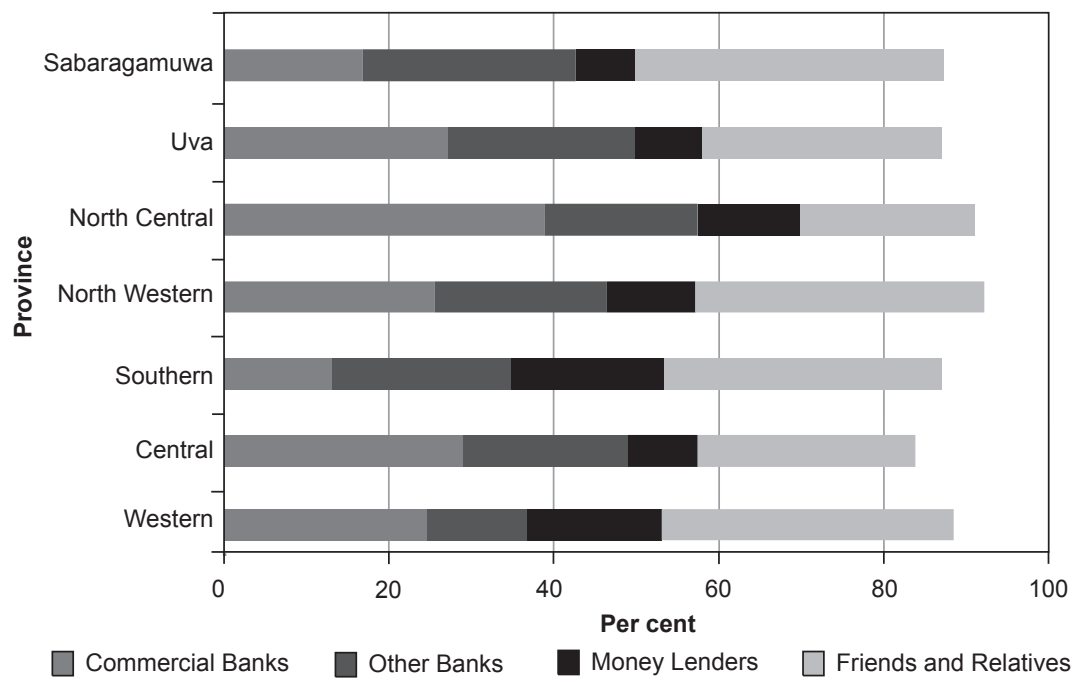

Source : Central Bank of Sri Lanka, Consumer Finance and Socio Economic Survey (CFSES) 2003/04

When the breakdown of individual sources of credit is considered, commercial banks were easily the most prominent individual source, among formal sources, in all provinces. It is observed that in provinces other than the NWP, commercial banks accounted for a larger share of loans taken by the non-poor category than by the BOP households. As could be expected, share of loans obtained from commercial banks was greatest in the NCP where 38.8 per cent and 40.0 per cent of the number of loans taken by BOP and non-poor households respectively, were from commercial banks. The corresponding share was least in the Southern Province where only 13.2 per cent of the number of loans taken by BOP households and 17.5 per cent of the number of loans taken by the non-poor category were sourced from commercial banks. Meanwhile, the share of loans obtained from development banks by BOP households varied from a high of 10.2 per cent in the Sabaragamuwa Province to a low of 4.1 per cent in the Southern Province. In the case of the non-poor category, the corresponding figure varied between a high of 13.7 per cent of loans in the Sabaragamuwa Province to a low of 5.6 per cent in the Central Province, indicating that Development Banks play a relatively more prominent role in credit delivery in the former Province. The share of loans taken from Development Banks by the BOP households exceeded the relevant share taken by the non-poor category only in the Western and Central Province which seems to indicate an absence of poverty focus in lending by Development Banks in the other five provinces. Credit exposure to other Development Finance Institutions was 
very low in all provinces. Meanwhile, rural banks were a relatively more important source in the Southern Province accounting for 9.7 per cent of the number of loans taken by the BOP households and 9.3 per cent of the number of loans taken by the non-poor category in that province. The corresponding figures for the other provinces were relatively lower. As could be expected, Samurdhi/Janashakthi banks, given their poverty focus, were a more important source of credit for BOP households than for non-poor households. Among BOP households, the share of loans taken from these banks were relatively high in the Southern and Uva Provinces where 7.3 per cent and 8.0 per cent respectively of the number of loans of BOP households were sourced from Samurdhi Banks. To a certain extent therefore, borrowers in the Southern Province, particularly the poor appear to have substituted rural banking and Samurdhi/Janashakthi banking services for commercial banking services. We shall see later that financial inclusion is greatest in the Southern Province and therefore, rural banks and Samurdhi/Janashakthi Banks appear to have achieved significant outreach in the Province. However, we also observed that despite this situation, BOP households in the Southern Province have taken a relatively large share of loans from informal sources. This suggests the presence of factors that lead to a preference for informal financing among borrowers in the Southern Province despite having access to the formal financial sector. These may be due to a number of factors to be discussed later.

The importance of formal sector employers as a source of credit varied across provinces. For BOP households, the proportion of loans obtained from such sources varied between a low of 0.7 per cent of the number of loans in the NWP to a high of 10.3 per cent of the number of loans in the Central Province. Among the non-poor, this variation was from a low of 5.3 per cent of the number of loans, again in the NWP, to a high of 20.0 per cent of the number of loans, again in the Central Province. This source of credit was more prominent among the non-poor group as could be expected, owing to the fact that a larger proportion of employees in this category would be in formal sector employment. However, the relatively high proportion of loans from this source, even among BOP households, in the Central Province probably partly reflects credit extended to estate workers by the estate management.

Among informal sources of credit, the most important source was friends and relations reflecting the social safety net provided by the "kinship and friendship network" in times of vulnerability. The proportion of loans taken by BOP households from this source varied between a high of 37.5 per cent in the Sabaragamuwa Province to a low of 21.1 per cent in the NCP. Further, among BOP households, the number of loans taken from friends and relations exceeded those taken from commercial banks in all provinces other than the NCP and Central Province. However, if the distribution is considered in terms of the value of loans taken, the ranking could be different as friends and relations generally provide loans of lesser value than institutional sources. Meanwhile, even in the non-poor category, friends 
and relations are an important source of credit accounting for between 18.3 per cent (NCP) and 31.2 per cent (NWP) of the number of loans for the different provinces, by this category. In fact, in the Southern Province and NWP, friends and relations ranked above commercial banks in terms of the number of loans taken even by households in the non-poor category. It should be noted that all informal loans provided without interest were considered to be from friends and relations in the CFSES. Thus these sources could also be linked to the borrowers in ways other than kinship and friendship (e.g.: being the landlord, employer, input supplier, output purchaser, of the borrower). Such links would reduce the risk to the lender. Further, although interest was not charged, hidden costs including reciprocal credit obligations when the lender is in need, obligations to provide free/subsidized labour, payment in kind and obligation to sell produce at a specified price may be involved in these loans.

The other major source of informal credit were money lenders. It should be noted that all informal sources of credit which charged an interest were categorised as money lenders, even if such sources did not traditionally engage in professional or semi professional money lending. Therefore, a large proportion of those categorised as money lenders are also likely to be those maintaining links described in the previous paragraph with the borrower. In such instances, risks involved in the loans would be less and hence interest rates could also be expected to be lower than those charged by professional/semi professional money lenders but hidden costs discussed earlier could be involved.

The proportion of loans obtained from money lenders by BOP households varied from a high of 18.3 per cent in the Southern Province to a low of 7.3 per cent in the Sabaragamuwa Province. The corresponding variation in respect of the non-poor category ranged from 13.2 per cent in the Western Province to 6.6 per cent in both the Uva and NCP. The proportion of loans taken from money lenders was less for the non-poor category when compared to BOP households in all provinces other than Sabaragamuwa. In the Central, Uva and Sabaragamuwa Provinces, the proportion of loans taken from money lenders by BOP households was significantly lower than the corresponding proportion in the other four provinces. Next to friends and relations, the most prominent source of credit (in terms of number of loans taken) for the BOP households in the Southern Province was money lenders. It is somewhat paradoxical that BOP households in the Southern and the Western Provinces have a greater dependence on money lenders than BOP households in the most backward Uva Province. As mentioned earlier, despite the relatively higher share of loans obtained from the informal sector, financial inclusion will also be found to be greatest in the Southern Province. High dependence on informal sources despite access to formal sources may be due to a number of reasons including lack of flexibility in terms and conditions attached to lending, lack of suitable financial products and inadequacy/deficiencies in the service provided by the formal financial sector institutions. 
Meanwhile, for BOP households, money lenders were the third most prominent source of credit (ranking after commercial banks and friends and relations) in terms of number of loans provided in the Western, NCP, NWP, and Uva Provinces. However in the Central, Uva and Southern Provinces, formal sector employers were the third most important source of credit for the non-poor category, while in the Sabaragamuwa Province development banks were the third most prominent source of credit for that category.

\section{Table 5 - Distribution of Loans by Type of Collateral and Province BOP and Non-Poor Households}

\begin{tabular}{|l|r|r|r|r|r|r|r|r|r|r|r|r|r|r|}
\hline & \multicolumn{2}{|c|}{ Western } & \multicolumn{2}{|c|}{ Central } & \multicolumn{2}{|c|}{ Southern } & \multicolumn{2}{|c|}{ NWP } & \multicolumn{2}{|c|}{ NCP } & \multicolumn{2}{|c|}{ Uva } & \multicolumn{2}{l|}{ Sabaragamuwa } \\
\cline { 2 - 12 } & BOP & NP & BOP & NP & BOP & NP & BOP & NP & BOP & NP & BOP & NP & BOP & NP \\
\hline No Security & 56.0 & 48.0 & 42.3 & 46.3 & 60.1 & 49.9 & 50.5 & 44.2 & 25.3 & 32.3 & 45.9 & 34.9 & 56.3 & 45.6 \\
Pronotes & 1.5 & 1.6 & 0.0 & 0.0 & 0.0 & 0.0 & 0.0 & 0.0 & 0.0 & 0.0 & 1.9 & 0.0 & 0.0 & 0.8 \\
Personal Guarantees & 6.0 & 11.3 & 15.9 & 12.4 & 16.8 & 21.9 & 18.0 & 16.1 & 21.8 & 23.6 & 15.7 & 20.7 & 11.8 & 18.4 \\
Immovable Property & 0.0 & 1.7 & 0.0 & 0.0 & 0.7 & 2.4 & 1.8 & 1.6 & 0.0 & 0.0 & 0.6 & 4.3 & 0.0 & 2.8 \\
EPF & 0.0 & 0.5 & 0.0 & 0.0 & 0.0 & 0.0 & 0.0 & 0.0 & 0.0 & 0.0 & 0.6 & 0.7 & 0.8 & 1.3 \\
Jewellery / Consumer & & & & & & & & & & & & & & \\
Durable Goods & 36.5 & 35.4 & 40.9 & 34.8 & 21.3 & 23.5 & 28.8 & 35.7 & 46.5 & 39.6 & 35.2 & 37.8 & 30.6 & 30.8 \\
Machinery & 0.0 & 0.2 & 0.0 & 0.0 & 0.0 & 0.0 & 0.0 & 0.0 & 0.0 & 0.0 & 0.0 & 0.0 & 0.0 & 0.0 \\
Other & 0.0 & 1.2 & 0.0 & 0.0 & 0.0 & 0.0 & 0.9 & 0.3 & 1.1 & 1.2 & 0.0 & 0.0 & 0.5 & 0.0 \\
Not Specified & 0.0 & 0.0 & 0.0 & 0.0 & 0.0 & 0.0 & 0.0 & 0.0 & 0.0 & 0.0 & 0.0 & 0.0 & 0.0 & 0.4 \\
\hline Total & 100.0 & 100.0 & 100.0 & 100.0 & 100.0 & 100.0 & 100.0 & 100.0 & 100.0 & 100.1 & 100.0 & 100.0 & 100.0 & 100.0 \\
\hline
\end{tabular}

Table 5 above gives the distribution of the number of loans taken by type of security for BOP and non-poor households. It is clear that a substantial proportion of loans have been granted without security. This proportion for BOP households varied from a high of 60.1 per cent in the Southern Province to a low of 25.3 per cent in the NCP. For the non-poor category, the relevant proportion varied from a high of 49.9 per cent in the Southern Province to a low of 32.3 per cent again in the NCP. NCP is the province which has the largest share of loans sourced from banks and this is probably the reason for collateral free loans being relatively low, as banks usually require some sort of security, even if not in a physical form. On the other hand, the availability of sources providing collateral free loans from the informal sector could be a contributory factor for the high informal borrowing observed in the Southern Province, despite that province having the greatest access to formal sector sources of credit, as we shall see later. In the Western, Southern, NWP and Sabaragamuwa Provinces, the proportion of collateral free loans taken by BOP households exceeded 50 per cent. As in some instances the proportion of collateral free loans exceeded the 
proportion of loans taken from informal sources, it is clear that there are sources providing collateral free credit in both the formal and informal sectors.

Among the types of collateral, the most popular by far was jewellery and consumer durables. The proportion of loans taken against jewellery and consumer durables by BOP households varied from a high of 46.5 per cent in the NCP to a low of 21.3 per cent in the Southern Province. The corresponding proportion for the non-poor category varied between 39.6 per cent in the NCP to 23.5 per cent in the Southern Province. In three of the provinces, Western, Central and NCP, the proportion of loans taken against jewellery and consumer durables was higher for the BOP households than for the non-poor category, whereas in the other 4 provinces the converse was true. Therefore, both the poor and the non-poor resort to the practice of putting up jewellery as collateral when borrowing. Further, jewellery is taken as collateral by both informal sector sources such as money lenders as well as formal sector lenders such as banks which offer pawning facilities.

Next to jewellery and consumer durables, the most frequently used form of collateral was personal guarantees. Use of personal guarantees as collateral was more frequent among borrowers in the NCP; 21.8 per cent of loans taken by the BOP households and 23.6 per cent of loans taken by the non-poor category in that province was taken on personal guarantees. As the share of credit sourced from commercial banks was highest in the NCP, it could be deduced that a fair share of these loans were granted against personal guarantees. Loans given under inter-se guarantee under the NCRCS would also have been included in this category. However, even in this province, the share of loans granted against jewellery and consumer durables exceeded by far the share granted against personal guarantees. Meanwhile, reliance on personal guarantees was least in the Western Province. In this more urbanised province where economic activity is more complex and social ties are less strong, mutual knowledge among residents on the financial positions of their counterparts would be lacking and this would result in a general reluctance to stand as guarantors for another person's loan. Except in the Central Province and the NWP, the proportion of loans taken under personal guarantees was higher for the non-poor category than for the BOP households. This could be expected as the more affluent would be in a better position to be more closely associated with persons with sufficient wealth and status to stand as personal guarantors. However, the significant share of loans obtained under personal guarantees even by BOP households indicate that the poor are not incapable of finding individuals to guarantee their loans. This is in stark contrast to the situation existing in Bangaladesh at the time of Prof. Yoonus's pioneering work on lending to the poor, where the ultra poor were not in a position to produce guarantors and as a result were shut out from institutional credit. 
Table 6 - Distribution of Loans taken by Interest Rate and Province

\begin{tabular}{|c|c|c|c|c|c|c|c|c|c|c|c|c|c|c|}
\hline & \multicolumn{2}{|c|}{ Western } & \multicolumn{2}{|c|}{ Central } & \multicolumn{2}{|c|}{ Southern } & \multicolumn{2}{|c|}{ NWP } & \multicolumn{2}{|c|}{ NCP } & \multicolumn{2}{|c|}{ Uva } & \multicolumn{2}{|c|}{ Sabaragamuwa } \\
\hline & BOP & NP & BOP & NP & BOP & NP & BOP & NP & BOP & NP & BOP & NP & BOP & NP \\
\hline Interest Free & 33.5 & 34.1 & 36.2 & 39.1 & 38.8 & 35.5 & 32.1 & 33.0 & 20.9 & 21.2 & 32.0 & 30.3 & 44.6 & 31.6 \\
\hline $1-10$ & 6.9 & 9.1 & 8.0 & 9.6 & 6.7 & 10.6 & 5.3 & 7.4 & 13.2 & 11.3 & 9.4 & 6.3 & 2.9 & 4.7 \\
\hline $11-20$ & 36.5 & 36.8 & 40.6 & 39.4 & 27.6 & 34.5 & 40.0 & 40.1 & 47.0 & 46.9 & 40.6 & 50.5 & 33.4 & 43.1 \\
\hline $21-30$ & 6.2 & 7.1 & 8.1 & 7.4 & 9.2 & 9.2 & 8.7 & 7.5 & 11.4 & 13.5 & 9.6 & 5.6 & 10.3 & 8.8 \\
\hline $31-40$ & 0.0 & 0.6 & 0.0 & 0.6 & 0.7 & 1.1 & 3.2 & 2.6 & 3.3 & 0.6 & 1.9 & 0.5 & 0.9 & 1.2 \\
\hline $41-50$ & 2.1 & 1.2 & 0.0 & 0.2 & 0.4 & 0.4 & 0.0 & 1.2 & 0.0 & 0.3 & 0.0 & 0.5 & 0.7 & 0.6 \\
\hline $51-60$ & 2.6 & 1.4 & 2.6 & 1.6 & 2.0 & 0.9 & 2.1 & 1.7 & 3.6 & 2.1 & 1.5 & 0.5 & 1.4 & 2.4 \\
\hline $61-70$ & 0.0 & 0.0 & 0.5 & 0.0 & 0.0 & 0.0 & 0.0 & 0.0 & 0.0 & 0.0 & 0.0 & 0.0 & 0.0 & 0.0 \\
\hline $71-80$ & 0.4 & 0.3 & 0.3 & 0.3 & 0.4 & 0.0 & 0.0 & 0.2 & 0.0 & 0.0 & 0.0 & 0.0 & 0.0 & 0.4 \\
\hline $81-90$ & 0.0 & 0.2 & 0.5 & 0.0 & 0.0 & 0.1 & 0.0 & 0.9 & 0.0 & 0.0 & 0.3 & 0.2 & 0.0 & 0.4 \\
\hline $91-100$ & 1.1 & 0.7 & 0.0 & 0.2 & 0.3 & 0.4 & 0.3 & 0.6 & 0.0 & 0.6 & 0.0 & 0.0 & 0.5 & 0.0 \\
\hline Over 100 & 10.7 & 8.2 & 2.9 & 1.7 & 13.8 & 7.2 & 8.4 & 4.7 & 0.5 & 3.5 & 3.7 & 4.7 & 5.3 & 5.9 \\
\hline Not Specified & 0.0 & 0.0 & 0.5 & 0.0 & 0.0 & 0.0 & 0.0 & 0.0 & 0.0 & 0.0 & 1.0 & 1.0 & 0.0 & 0.8 \\
\hline Total & 100.0 & 100.0 & 100.0 & 100.0 & 100.0 & 100.0 & 100.0 & 100.0 & 100.0 & 100.0 & 100.0 & 100.0 & 100.0 & 100.0 \\
\hline $\begin{array}{l}\% \text { borrowing at } \\
\text { over } 30 \%\end{array}$ & 17.0 & 12.9 & 7.2 & 4.6 & 17.6 & 10.1 & 14.0 & 12.0 & 7.4 & 7.2 & 8.4 & 7.3 & 8.7 & 11.7 \\
\hline
\end{tabular}

Source : Central Bank of Sri Lanka, Consumer Finance and Socio Economic Survey (CFSES) 2003/04

\section{Chart 4-Composition of Loans obtained at High Level Interest and Loans obtained from Money Lenders - BOP Households}

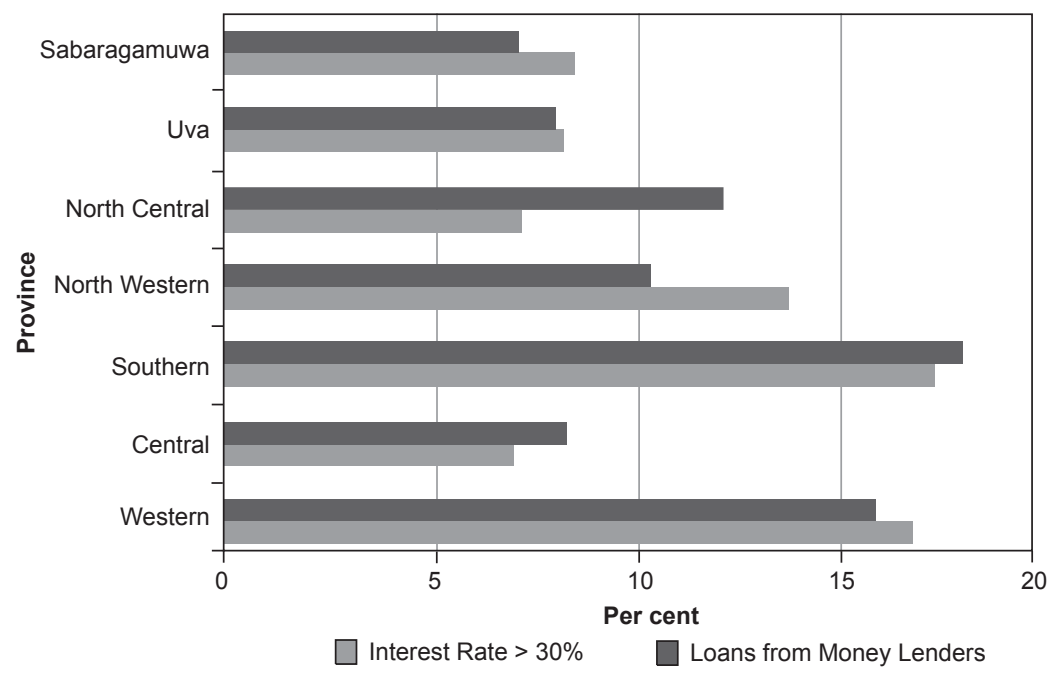

Source : Central Bank of Sri Lanka, Consumer Finance and Socio Economic Survey (CFSES) 2003/04 
Table 6 above gives the distribution of loans by the rate of interest for BOP households and the non-poor category, while Chart 4 below compares the share of loans taken from money lenders with the share of loans obtained at interest rates exceeding 30 per cent for BOP households. This table indicates that in most provinces, the distribution is bi-model for both categories of households, peaking at interest rate 0 (interest free) and the 11-20 per cent range. Interest free loans are provided mainly by friends and relations, a relatively prominent source of credit, while the interest range 11-20 per cent corresponds roughly to interest rates prevailing in formal sector financial institutions.

The proportion of loans obtained interest free varied from a high of 44.6 per cent in the Sabaragamuwa Province to a low of 20.9 per cent in the NCP for BOP households, while for the non-poor category the corresponding variation was from a high of 39.1 per cent in the Central Province to a low of 21.2 per cent, again in the NCP. Interest free loans are of course mainly provided by friends and relations whereas all financial institutions generally charge interest. In the Central, Southern, Uva and Sabaragamuwa provinces, the proportion of loans obtained interest free by BOP households exceeded the proportion of loans provided by friends and relations. This implies that there are sources other than friends and relations prepared to provide interest free loans. As it is unlikely that banks and other financial institutions would resort to such a practice, probably these loans are provided mainly by formal sector employers.

Except in the case of both categories of households in the Southern Province and BOP households in the Sabaragamuwa Province, loans taken at interest rates ranging from 11-20 per cent exceeded loans taken without interest. The share of loans taken at the interest range 11-20 per cent by BOP households in the different provinces ranged between a high of 47.0 per cent in the NCP to a low of 27.6 per cent in the Southern Province. For the nonpoor category, the corresponding proportion varied between a high of 50.5 per cent in the Uva Province and a low of 34.5 per cent in the Southern Province. This is consistent with our earlier observations that the share of loans sourced from commercial banks was least in the Southern Province. Therefore, one of the reasons for informal sector preference of Southern Province households is possibly the greater availability of interest free loans in the informal sector in that province. The higher share of loans obtained from the banking system in the NCP was earlier attributed to the popularity of special loan schemes that provide a relatively higher quantum of loans to that province. In fact, the proportion of loans obtained in the interest range 1-10 per cent was also relatively higher in the NCP suggesting participation in interest subsidy schemes. It should be noted that the share of loans in the interest range 11-20 per cent taken by BOP households in the Uva and Sabaragamuwa provinces was about 10 percentage points less than the corresponding share for the non-poor category in these two provinces. The situation is different in the case of loans in the next higher interest range of 21-30 per cent, reflecting clearly the disadvantage suffered 
by the poor when obtaining loans at a reasonable rate of interest in these two provinces. On the other hand, although the poor - non-poor disparity in access to loans in the interest range 11-20 per cent is sharp in the Uva and Sabaragamuwa Provinces, the share of loans obtained at this relatively moderate interest range by BOP households in these two provinces, exceeds the corresponding figures for BOP households in the Southern Province. In fact, the proportion of loans obtained by BOP households in the Southern Province at interest rates below 20 per cent was 73 per cent whereas for BOP households in Uva and Sabaragamuwa the corresponding proportion exceeded 80 per cent implying that low income households in the Southern Province are at an even greater disadvantage than those in the more poverty striken Uva and Sabaragamuwa Provinces when it came to obtaining loans at a reasonable cost.

In most cases, institutional credit, even micro credit would have carried interest rates below 30 per cent during the survey period and therefore it is very likely that interest rates above 30 per cent would have been charged mainly by informal money lenders. This is consistent with the earlier finding that the proportion of loans taken with interest rates above 30 per cent by BOP households corresponds closely with the proportion of loans taken from money lenders in most provinces (see chart 4). The chart indicates however that in the NCP, the share of loans obtained from money lenders significantly exceeds the share of loans taken at interest rates above 30 per cent, implying that a notable proportion of money lenders providing loans to low income households in this province in fact do so at interest rates below 30 per cent. This could be attributed both to the relatively greater competition offered by the formal sector institutions to moneylenders in the province and given the predominance of agriculture in this province the fact that a substantial amount of those classified as money lenders are in fact providing "produce based credit" as produce buyers and land lords etc. On the other hand, in the NWP, the share of loans obtained at interest rates above 30 per cent by BOP households exceeds the proportion of loans obtained by them from money lenders indicating that sources other than money lenders also charge exorbitant interest rates in the province. Earlier, we observed that in the NWP a notable share of loans was taken for debt servicing by the BOP category. This suggests that there is a fairly serious debt problem in that province. It is significant that the proportion of loans with interest rates above 30 per cent was higher for BOP households than for the non-poor category in all provinces other than Sabaragamuwa, again highlighting the disadvantage suffered by the poor in obtaining loans at a reasonable cost. Sabaragamuwa Province seems to be an outlier with BOP households enjoying substantial access to interest free credit. In the Western, Southern and NWP, the share of loans taken at interest rates in excess of 30 per cent were at double digit levels for both categories of households with the corresponding proportion for BOP households in the Western and Southern Provinces exceeding 17 per cent (see Table 6). In fact, in these two provinces, the proportion of loans taken at interest rates above 100 per cent by BOP households was also at double digit 
levels implying greater dependence on exploitative money lenders. This is consistent with our findings earlier that it is the poor in the Western and Southern Provinces that are most dependent on money lenders. In the Southern Province, the proportion of BOP households obtaining loans at interest rates exceeding 30 per cent was 7.5 percentage points higher than the corresponding proportion for the non-poor category in the same province. Despite the greater poverty headcount in the Uva province, the proportion of loans taken at interest rates exceeding 30 per cent was at low single digit levels, even for the BOP group.

While the above analysis indicates that the poor are at a comparative disadvantage when accessing institutional credit and are therefore more dependent on informal sources, there does not appear to be a very strong difference between the borrowing patterns of BOP households and the non-poor category. In fact, provincial variations were seen to overshadow poor - non-poor disparity in borrowing patterns.

Generally, the source of loan chosen is determined by the purpose for which the loan is sought. Loans for day to day general consumption purposes and exigencies are more likely to be sourced from informal sources, even among persons with access to financial institutions, due to the lessor availability of loans for consumption purposes in the institutional sector. On the other hand, loans related to production purposes have a greater likelihood of being sources from formal sources, particularly if there is a special credit scheme in place for such loans by which the bank benefits (i.e. receives interest subsidy payments or refinance) or if the business plan relating to the project is acceptable and indicates a cash flow by which the loan could be serviced with ease.

Table 7 below gives the unbanked households by income quintiles, computed as explained earlier.

Table 7 - Percentage of “Un-banked Households” by Income Quintile 2003/2004

\begin{tabular}{|c|c|c|c|c|c|c|c|}
\hline Quintile / Category & Western & Central & Southern & NWP & NCP & Uva & $\begin{array}{c}\text { Sabara- } \\
\text { gamuwa }\end{array}$ \\
\hline 1 & 33.1 & 36.9 & 24.9 & 32.6 & 36.8 & 42.9 & 35.7 \\
2 & 24.5 & 29.3 & 18.9 & 19.6 & 19.0 & 31.2 & 28.5 \\
2 & 19.1 & 27.5 & 15.9 & 21.6 & 13.7 & 21.7 & 23.1 \\
4 & 16.2 & 22.1 & 11.9 & 12.0 & 11.1 & 17.2 & 18.2 \\
5 & 11.5 & 12.4 & 5.6 & 7.6 & 11.8 & 12.2 & 7.4 \\
\hline Unbanked BOP & $\mathbf{3 3 . 1}$ & $\mathbf{3 5 . 2}$ & $\mathbf{2 3 . 0}$ & $\mathbf{2 9 . 2}$ & $\mathbf{3 4 . 5}$ & $\mathbf{3 7 . 5}$ & $\mathbf{3 4 . 5}$ \\
Households (a) & $\mathbf{4 . 6}$ & $\mathbf{9 . 1}$ & $\mathbf{6 . 7}$ & $\mathbf{7 . 9}$ & $\mathbf{7 . 9}$ & $\mathbf{1 3 . 9}$ & $\mathbf{8 . 3}$ \\
\hline $\begin{array}{l}\text { Unbanked BOP Households } \\
\text { as a \% of Total Households }\end{array}$ & & & & & & & \\
\hline
\end{tabular}

(a) Proportion in the BOP category deemed to be unbanked. 
As could be expected, in general, the percentage of un-banked households declines with increasing income. However, the relationship with income is not as strong as expected due to the fact that the figures for the proportion of unbanked households is much more likely to be overestimated for non-poor households than for BOP households. Accordingly, the proportion of unbanked households is likely to be substantially lower for the upper quintiles than indicated by the figures given in the table above.

The table reveals that the highest proportion of unbanked BOP households is found in the Uva province where 37.5 per cent of such households were unbanked. All provinces other than the Southern Province and NWP had over a 30 per cent of BOP households falling into the unbanked category. The Southern Province has the least proportion of unbanked BOP households (23.0 per cent), which at a first glance seems to contradict the earlier finding that there was significantly greater dependence on informal sources for credit by the poor in that province.

Table 8 below gives estimates of financial inclusion by income quintile and province based on above estimates for unbanked households while chart 5 compares the estimates for financial inclusion for BOP households across the provinces. In accordance with the estimation methodology explained earlier, a household that had undertaken any transactions relating to financial assets (inclusive of receipt of interest to their savings/fixed deposits) or engaged in a loan related transaction with a financial institution during the 6 months preceding the date of enumeration was deemed to have access to formal sector financial institutions. Consequently, as discussed earlier, households with access to financial services not undertaking any of the above mentioned transactions during the reference period and the self excluded would erroneously not be counted as households with access to finance. This makes the figures for financial inclusion given in the table 8 below, underestimates. Therefore, these estimates could be considered lower bounds for financial inclusion.

Table 8 - Estimates of Financial Inclusion by Quintiles for Provinces

\begin{tabular}{|c|c|c|c|c|c|c|c|}
\hline Quintile & Western & Central & Southern & NWP & NCP & Uva & $\begin{array}{c}\text { Sabara- } \\
\text { gamuwa }\end{array}$ \\
\hline 1 & 66.9 & 63.1 & 75.1 & 67.4 & 63.2 & 57.1 & 64.3 \\
2 & 75.5 & 70.7 & 81.1 & 80.4 & 81.0 & 68.8 & 71.5 \\
3 & 80.9 & 72.5 & 84.1 & 78.4 & 86.3 & 78.3 & 76.9 \\
4 & 83.8 & 77.9 & 88.1 & 88.0 & 88.9 & 82.8 & 81.8 \\
5 & 88.5 & 87.6 & 94.4 & 92.4 & 88.2 & 87.8 & 92.6 \\
\hline All & 79.1 & $\mathbf{7 4 . 3}$ & $\mathbf{8 4 . 5}$ & $\mathbf{8 1 . 3}$ & $\mathbf{8 1 . 5}$ & $\mathbf{7 5 . 0}$ & $\mathbf{7 7 . 4}$ \\
\hline
\end{tabular}

Source : Central Bank of Sri Lanka, CFSES 2003/04 - Special Tabulations 


\section{Chart 5 - Financial Inclusion by Province}

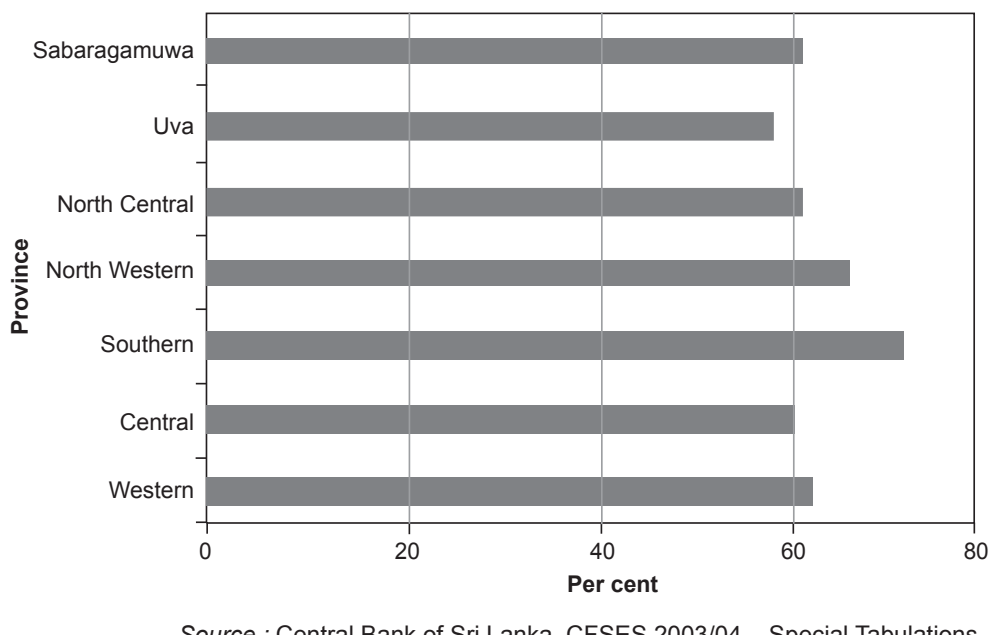

Interestingly, as mentioned earlier, overall financial inclusion was greatest, not in the most developed Western Province, but in the Southern Province where 84.5 per cent of households had reportedly used formal financial services, while the least access is found in the Central and Uva provinces with the corresponding figures standing at 74.3 per cent 75 per cent of households respectively. In the Southern Province, NWP and NCP, over 80 per cent of households had access to financial services. In fact, these three provinces scored better with respect to financial inclusion than the most developed and affluent Western Province. Despite the underestimation explained earlier, the above figures confirm that financial inclusion in Sri Lanka is substantially higher than in other countries in the region such as India, Pakistan and Bangaladesh. According to the Rural Finance Survey of 2003 for India, 79 per cent of households did not have access to formal loans and 59 per cent did not have access to formal savings services. Another study revealed that less than 20 per cent of rural Indians have access to formal financial services. In Pakistan, it is revealed that only 30 per cent of adults have bank accounts and the total number of borrowers from banking institutions constitutes only 3 per cent of the population. Despite this situation, there is no room for complacency in Sri Lanka, particularly as substantial borrowing from the informal sector is observed among the household population alongside borrowing from the financial sector, suggesting that financial access could be only partial for a notable proportion of the population. Ironically, in the Southern Province where financial access is greatest, even for low income households, borrowing, in terms of proportion of loans taken, from the informal sector is also highest. It was noted earlier that in the Southern Province, households obtain a substantial amount of loans from rural and cooperative banks rather than from commercial 
banks. It may be worthwhile investigating as to why a notable proportion of households in this province prefer not to borrow from conventional commercial banks and instead opt to borrow from other banks and informal sources. For this purpose, an assessment should be made as to the extent to which products offered by commercial banks and terms and conditions attached to such products meet the needs of Southern Province households. Data suggests that the preference for borrowing from the informal sector by households in this province could be the greater availability of loans without interest and collateral requirements in the informal financial sector in the province. Therefore, relaxation of rigid collateral requirements and offering of products suited to the special needs of the province would encourage borrowing from formal sector institutions.

\section{Unmet Demand for Microfinance}

Table 9 - Unmet Demand for Micro Finance

\begin{tabular}{|c|c|c|c|c|c|c|c|}
\hline & Western & Central & Southern & NWP & NCP & Uva & $\begin{array}{l}\text { Sabara- } \\
\text { gamuwa }\end{array}$ \\
\hline No. of Households 1996/97 & $1,020,600$ & 503,005 & 509,461 & 498,603 & 251,657 & 244,683 & 391,010 \\
\hline $\begin{array}{l}\text { Percentage of Total Households which are } \\
\text { unbanked and belonging to the BOP category } \\
1996 / 97\end{array}$ & 3.9 & 10.4 & 7.8 & 9.8 & 7.4 & 12.7 & 11.7 \\
\hline Estimated unbanked BOP households 1996/97 & 39,803 & 52,313 & 39,738 & 48,863 & 18,623 & 31075 & 45,748 \\
\hline No. of Households 2003/2004 & $1,291,833$ & 573,857 & 521,502 & 541,810 & 271,967 & 280,301 & 434,718 \\
\hline $\begin{array}{l}\text { Percentage of Total Households which are } \\
\text { unbanked and belonging to the BOP category } \\
2003 / 04\end{array}$ & 4.6 & 9.1 & 6.7 & 7.9 & 7.9 & 13.9 & 8.3 \\
\hline $\begin{array}{l}\text { Estimated unbanked BOP Households in } \\
2003 / 2004\end{array}$ & 59,424 & 52,221 & 34,941 & 42,803 & 21,485 & 38,962 & 36,082 \\
\hline $\begin{array}{l}\text { Scenario } 1^{*} \text { - No. of Estimated Unbanked } \\
\text { Households in the BOP category in } 2008\end{array}$ & 74,903 & 52,335 & 32,540 & 39,765 & 23,381 & 44,492 & 31,570 \\
\hline $\begin{array}{l}\text { Scenario } 2^{* *}-\text { No. of Estimated Unbanked } \\
\text { Households in the BOP category in } 2008\end{array}$ & 63,064 & 58,239 & 39,922 & 46,488 & 25,135 & 43,768 & 39,549 \\
\hline $\begin{array}{l}\text { Resources required to enroll unbanked BOP } \\
\text { households in microfinance programmes } \\
\text { - Scenario } 1 \text { (Rs.mn.) }\end{array}$ & $1,498.1$ & $1,046.7$ & 650.8 & 795.3 & 467.6 & 889.8 & 631.4 \\
\hline $\begin{array}{l}\text { Resources required to enroll unbanked BOP } \\
\text { households in microfinance programmes } \\
\text { - Scenario } 2 \text { (Rs.mn.) }\end{array}$ & 1,261 & 1,167 & 798.4 & 930 & 503 & 875 & 791 \\
\hline
\end{tabular}

* Scenario 1 - Assuming that the annual rate of growth of unbanked BOP between the period 1996/97 and 2003/04 has continued until $2007 / 08$.

** Scenario 2 - Assuming that the proportion of unbanked BOP households would not have changed from the level existing in 2003/04. 
Estimates of the number of households in the BOP group without bank exposure given in Table 9 reflects the regional potential for expanding microfinance. Province wise estimates in the table were undertaken on the basis of 2 scenarios. In the first scenario, it was assumed that the annual growth trend in the number of unbanked households between the survey years 1996/97 and 2003/2004 would continue until 2008. In the second scenario, the proportion of unbanked households was assumed to be invariant at the level that prevailed in 2003/04.

According to the above projections, the number of unbanked potential microfinance client households in the seven provinces under review was estimated to be 298,986 under scenario 1 and 316,255 under scenario 2. Accordingly, it would be safe to conclude that the number of potential microfinance clients yet to be reached by poverty alleviation micro finance programmes in Sri Lanka in these seven provinces would be around 300,000. The lowest proportion of unbanked BOP households in both surveys was observed in the Western Province. However, CFSES information indicates that over the survey years, this proportion has increased from 3.9 per cent in 1996/97 to 4.6 per cent in 2003/04, suggesting that the informal financial sector actually expanded in the province. In fact, as discussed below, the absolute number of unbanked households estimated for the year 2008 is highest in the Western Province due to its high population density. Accordingly, one fourth of potential microfinance client households yet to be reached, live in the Western Province. In the NCP and Uva Provinces also, financial inclusion appears to have deteriorated between the two survey periods, although the deterioration in the case of the NCP is marginal and may be due to fluctuations in the demand for cultivation loans, which are dictated by extraneous factors like the receipt of rain/water on time etc., in those particular years. In any event, the $\mathrm{NCP}$ has the lowest number of potential micro finance client households still to be reached by formal sector financial institutions. In the Central, Southern, NWP and Sabaragamuwa Provinces, financial inclusion of the poor has improved as could be expected given the growth in bank branch networks etc. The deterioration in the financial inclusion situation in the Western and Uva Provinces are however a matter for concern as it appears that either the availability of formal financial services has not kept up with the population growth or that informal financial services offering more flexible terms and conditions have expanded possibly due to formal financial services not catering to the needs of poor households. This situation needs to be further investigated.

Chart 6 and 7 give the distribution of the absolute number of potential microfinance client households still to be reached by province. The number of unbanked BOP households was highest in the Western Province due to the relatively high population in the province under both scenarios described above: under scenario 1 , this number is estimated at 74,903 while under scenario 2 it is 63,064 . As observed earlier, one fourth to one fifth of the households that need to be reached by poverty alleviation microfinance programmes live 
Chart 6

Distribution of Microfinance Clients still to be reached - Scenario 1 Estimation

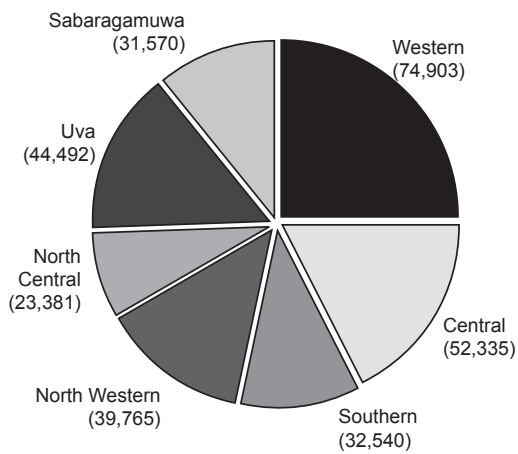

Chart 7

Distribution of Microfinance Clients still to be reached - Scenario 2 Estimation

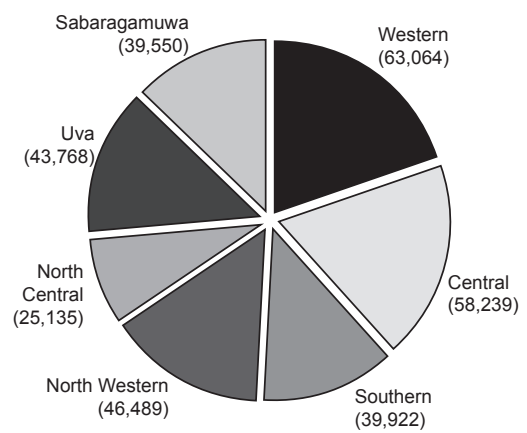

in the Western Province. Ranking next to the Western Province, in terms of the number of financially excluded BOP households is the Central Province for which the corresponding figures are estimated at 52,335 under scenario 1 and 58,239 under scenario 2. In both the Uva and NWP, the estimated number of financially excluded BOP households exceeds 39,000 . Formal financial sector penetration is relatively much more favourable in the less populated NCP where under both scenarios, the number of unbanked BOP households, were below 26,000, although the number of unbanked households increased slightly between the survey years 1996/97 and 2003/2004. The sharpest improvement in financial inclusion between the survey years is observed in the Sabaragamuwa Province. It is estimated that the number of BOP households needing microfinance services is 31,570 under scenario 1 and 39,549 under scenario 2 , for this province.

Table 9 also gives the initial resources required to enrol all unbanked households into poverty alleviation microfinance programmes under both scenarios. The figures reveal that around Rs. 6 billion is required for this purpose for the 7 provinces under consideration. (This is estimated on the basis of providing an initial loan of Rs.20,000 to each unbanked household.) Of this, Rs.1.3 to Rs.1.5 bn is required in the Western Province. It should be emphasized that this is not the total unmet demand for microfinance in the sense that as low income households already borrowing under microfinance programmes may be in need of further funds. 


\section{Summary and Conclusion}

Although banking services have expanded over the years, informal sources continue to provide an appreciable proportion of credit not only to the poorest households but also to the relatively more affluent. Friends and relations provide a notable proportion of credit for all categories of households, implying that strong social ties of kin-ship and friendship continue to be an important support mechanism in this country particularly during exigencies. Borrowing for non-productive purposes including consumption was significant for both the poor and non-poor although a larger share of loans of the poor were devoted for such non-productive purposes. This raises the issue as to whether micro-credit should be provided for non-productive purposes as well. In Sri Lanka, many microfinance programmes provide loans only for income generating activities. However, provision of loans for purposes such as education, health and general consumption is common in many microfinance schemes operated in other countries in the region and the design of such loan products should be studied before designing such products for the micro credit market in Sri Lanka. In any event, it should be noted that, money is fungible and there is no mechanism to prevent funds provided for income generating activities being diverted to other purposes. Further, all poor people do not have the entrepreneurial ability to set up and run independent micro enterprises. Wage labour could also benefit from poverty alleviation microfinance programs, if loan facilities are made available for purposes such as housing, health, education, lifecycle events emergencies and general consumption etc. This would be more relevant in an urbanized atmosphere, where the proportion of wage labour is high and opportunities for self employment relatively low. It is also very important to encourage savings in poverty alleviation microfinance programmes and ensure the availability of a flexible mechanism to permit the poor to access their own savings and/or group savings in times of need to meet their consumption and other needs that are not related to income generating activities. Perhaps, provision of bulk loans several times the value of group savings to groups could be considered for intra group lending for purposes not related to income generating activities. This would prevent loans given for livelihood activities being diverted for other purposes. Micro-insurance services need also to be in place to help the poor manage risks and emergencies.

As regional patterns dominate over income disparity, there appears to be no strong reason to design special loan products exclusively for the poor and any product which is popular for the non-poor in a region is likely to be popular among the poor as well. For example a loan product for life cycle events would be popular for both the poor and non-poor in the Central Province. However, flexible and high quality financial services should be provided at a reasonable cost to the poor to wean them away from usurious money lenders. 
The proportion of loans taken from formal and informal sources was higher for the non-poor category, when compared to the BOP category, supporting the premise that the poor face greater financial exclusion. However, the data shows that a greater proportion of the poor in Sri Lanka are served by the banking system than in other countries in this region. Despite this, both poor and non-poor resort to borrowing from the informal sector as well, suggesting that they are to some extent underserved by the formal financial sector and pointing to the need for infusing further flexibility in loan products to make them customer friendly. It should also be kept in mind that it is not possible to eliminate borrowing from informal sources totally, as a large proportion of such borrowings are from friends and relations on very flexible terms and conditions which the formal sector cannot match.

A somewhat paradoxical observation was that the proportion of loans taken from informal sources was high in the Southern Province, particularly for the poor, despite the access to formal finance being greatest in the province, with even the low income groups having comparatively greater access to credit. Although in all provinces households with access to finance also borrow from the informal sector, the situation seems to be more acute in the Southern Province. As observed earlier, this may be due to several factors such as having very rigid terms and conditions relating to credit delivery from formal sector institutions particularly collateral requirements which are unsuitable to borrowers and the availability of loans on more flexible and favourable terms and conditions in the informal sector etc. Further expansion of micro finance programmes under the Self Help Group (SHG) mechanism could help to alleviate the problem with regard to collateral to a certain extent as beneficiaries could then make use of inter-se guarantee. Banks would also be willing to accept such guarantees particularly if these microfinance programmes are managed by reputable organizations with good financial standing.

The precise level of interest charged by money lenders cannot be derived from the data, as all informal sector credit which included an interest component were lumped together and considered to have been sourced from money lenders in the CFSES 2003/04. For a better analysis of interest rates charged by professional money lenders it is necessary to separate money lenders with links to the borrower from those who lend to borrowers without such links. It seems that BOP households in the Western and Southern Provinces are more vulnerable to exploitation by money lenders than BOP households in the less developed Uva and Sabaragamuwa Provinces, as the proportion of loans taken at interest rates above 30 per cent was much higher for BOP households in the two former provinces than is the case with BOP households in the two latter provinces. This points to a need for a more flexible approach in credit delivery by financial institutions involved in micro credit activities in both the Western and Southern Provinces. The expansion of poverty alleviation micro finance programmes which use the SHG methodology by reputable entities in the Western and Southern provinces is therefore called for. 
Loans obtained at interest rates below 30 per cent varied between 82.4 per cent and 92.8 per cent for BOP households in the different provinces while the relevant figures ranged between 87.1 per cent and 95.4 per cent for the non-poor category. Although a larger proportion of loans with interest rates above 30 per cent was recorded for BOP households when compared to the non-poor category, the fact that even the BOP category were able to obtain over 80 per cent of their loans at interest rates below 30 per cent implies that it would be unlikely for the demand for microfinance to be completely interest inelastic in Sri Lanka as is the case of some other countries where the poor are completely cut-off from the financial sector. There is evidence in the $\mathrm{NCP}$ which suggests that where the formal sector successfully competes with the money lenders the interest rate charged by the latter can be driven down.

The number of microfinance clients yet to be reached is estimated to be around 300,000 in the seven provinces under consideration. Around a fourth of them reside in the Western Province. The share of unbanked population is observed to have increased in the Western and Uva provinces during the period 1997-2004. It may be worthwhile to study the causal factors that have led to this situation. As in absolute figures the number of unbanked households was in fact highest in the Western Province owing to its higher population density, there is ample scope for expanding micro finance activities in the province despite the fact that it is by far the richest province. However, most poverty alleviation programmes, particularly those that are donor funded exclude the Western Province on account of greater affluence. In negotiations undertaken relating to such programmes, it should be brought to the notice of donor agencies that the number of unreached potential micro finance client households is greatest in the Western province and that a large proportion of poor households in the province are dependent on the informal sector for credit. It is therefore extremely important to identify pockets of poverty within the province and target such pockets specifically under poverty alleviation microfinance programmes. It is worthwhile noting that urban poverty could cause greater social unrest which would have much graver implications for the law and order situation in the country.

In order to improve financial inclusion in the country, a deliberate attempt should be made to enrol unbanked households in poverty alleviation microfinance programmes. Targeting is very important as interest rates for ordinary commercial borrowing and microfinance overlap at present making the elite capture of microfinance in Sri Lanka a strong possibility. It is observed that field staff involved in microfinance programmes tend to enrol persons already with access to finance to programmes targeted to the poor and the relatively low level of interest rates in such programmes gives an incentive to the non-poor also to join such programmes. One way in which poverty alleviation microfinance programmes could improve financial inclusion is by providing bonus payments and incentives to field staff who enrol households without any previous access to formal sector finance. 


\section{References:}

Robinson Marguerite S ( 2001), "The Microfinance Revolution Sustainable Finance for the Poor" IBRD (Washington).

Sandaratne Nimal (2002), "Leading Issues in Rural Finance”, Postgraduate Institute of Agriculture University of Peradeniya.

Beartriz Armendariz \& Jonathan Morduch, (2007) "The Economics of Microfinance" MIT Press Cambridge Massachusetts London, England.

Bernd Balkenhol (2007), "Microfinance and Public Policy Outreach, Performance and Efficiency", International Labour Office.

Fernando Nimal A (2007), "Low-Income Households'Access to Financial Services; International Experience, Measures for Improvement and the Future" Asian Development Bank.

Central Bank of Sri Lanka (1999), Report of the Consumer Finance and Socio Economic Survey, Part I 1996/97.

Central Bank of Sri Lanka (2005), Report of the Consumer Finance and Socio Economic Survey, Part I 2003/04.

Sri Lanka German Development Co-operation (Promotion of the Microfinance Sector) (2008), Outreach of Financial Services in Sri Lanka.

Yunus Muhammad and Jolis Alan (1998), "Banker to the Poor" London: Aurum Press Ltd. 